\title{
Unravelling the role of microorganisms in arsenic mobilization using metagenomic techniques
}

\author{
J.R. Lloyd ${ }^{1}$, E.T. Gnanaprakasam ${ }^{1}$, N. Bassil ${ }^{1}$, B.E. van Dongen ${ }^{1}$, L.A. Richards ${ }^{1}$, \\ D.A. Polya ${ }^{1}$, B.J. Mailloux ${ }^{2}$, B.C. Bostick ${ }^{2} \&$ A. van Geen ${ }^{2}$ \\ ${ }^{1}$ School of Earth and Environmental Sciences, The University of Manchester, UK \\ ${ }^{2}$ Barnard College and Lamont-Doherty Earth Observatory, Columbia University, New York, NY, USA
}

\begin{abstract}
The contamination of groundwaters, abstracted for drinking and irrigation, by sediment-derived arsenic, threatens the health of tens of millions worldwide. Microbial processes are accepted as playing a key role in arsenic mobilisation from sediments into groundwaters, but the precise biogeochemical mechanisms remain a subject of debate. A combination of field investigations, coupled to laboratory experimentation with sediment samples using "microcosm" approaches, has provided a significant body of evidence supporting a key role for anaerobic metal-reducing bacteria in the reductive mobilization of arsenic in aquifers in West Bengal, Cambodia, Vietnam and Bangladesh. The application of high-throughput next generation sequencing, combined with metagenomic reconstructions and other "omics" techniques from the life sciences is shedding new insight into the processes at play, and identifying new mircoorganisms and coupled biogeochemical processes that control the solubility of arsenic in Asian aquifers.
\end{abstract}

\section{MICROBIALLY DRIVEN MOBILIZATION OF ARSENIC IN AQUIFERS: MICROCOSM STUDIES}

Field studies have shown that contamination of groundwater with naturally occurring arsenic in the subsurface poses a global public health crisis in many countries including Mexico, China, Hungary, Argentina, Chile, Cambodia, India (West Bengal), and Bangladesh. Although the mechanism of arsenic release from these sediments has been a topic of intense debate, there is broad consensus that microbially-mediated reduction of assemblages comprising arsenic (most likely as arsenate) sorbed to ferric oxyhydroxides is the dominant mechanism for the mobilization of arsenic into these groundwaters (Akai et al., 2004; Islam et al., 2004). For example, an early "microcosm"-based study from our group in Manchester provided direct evidence for the role of indigenous metal-reducing bacteria in the formation of toxic, mobile As(III) in sediments from the Ganges Delta (Islam et al., 2004). This laboratory study showed that the addition of acetate to anaerobic sediments, as a proxy for organic matter and a potential electron donor for metal reduction, resulted in stimulation of microbial reduction of Fe(III) followed by $\mathrm{As}(\mathrm{V})$ reduction and the subsequent release of As(III), presumably by As(V)-respiring bacteria that were previously respiring Fe(III). Microbial communities responsible for metal reduction and As(III) mobilization in the stimulated anaerobic sediment were analyzed using molecular (PCR) and cultivationdependent techniques. Both approaches confirmed an increase in numbers of metal-reducing bacteria, principally Geobacter species. Later work confirmed that Geobacter species are able to couple to oxidation of organic matter to the reduction of both $\mathrm{Fe}(\mathrm{III})$ oxides and $\mathrm{As}(\mathrm{V})$ that may be associated with the iron minerals within aquifer sediments.

Microbial communities in the subsurface are complex, and although they may become less diverse in laboratory microcosm incubations that are designed to mimic the biogeochemical conditions that support maximal levels of arsenic mobilization, identifying the causative organisms is challenging. One approach to identify the metabolically active causative organisms is to use stable isotope probing (SIP), which can link the active fraction of a microbial community to a particular biogeochemical process. This technique has been used to identify $\mathrm{As}(\mathrm{V})$-respiring bacteria in Cambodian aquifer sediments implicated in the reductive mobilization of arsenic (Rowland et al., 2007). 13C-labeled acetate was added to microcosm incubations, and promoted the reduction of the $\mathrm{As}(\mathrm{V})$ present in the sediments. PCR analysis of the "heavy" labeled DNA that was synthesized by the active fraction of the microbial community within the sediments (and separated from unlabeled "light" background nucleic acids by ultracentrifugation) led to the detection of known arsenate-respiring bacteria Desulfotomaculum sp. and Desulfosporosinus sp. from their characteristic 16S rRNA gene signatures. When $10 \mathrm{mMAs}(\mathrm{V})$ was added, to enrich for $\mathrm{As}(\mathrm{V})$-respiring bacteria, an organism closely related to the arsenate-reducing bacterium Sulfurospirillum strain NP4 was identified. This organism was also closely related to clones identified previously in West Bengal sediments associated with high arsenic concentrations. Functional gene analysis of sediments 
amended with $13 \mathrm{C}$-labeled acetate and $\mathrm{As}(\mathrm{V})$ that targeted the $\mathrm{As}(\mathrm{V})$ respiratory reductase gene $(\operatorname{arr} A)$ using highly specific PCR primers, identified gene sequences most closely related to those found in $S$. barnesii and G. uraniireducens. Subsequent highthroughput pyrosequencing of $13 \mathrm{C}$ amended, heavylabelled DNA from similar sediment incubations, have further emphasized the potential importance of organisms affiliated with known Geobacter species. Here, organisms most closely related to $G$. uraniireducens dominated and carried copies of the $\operatorname{arrA} \operatorname{As}(\mathrm{V})$ respiratory reductase gene, implicated in mediating As-release in laboratory incubations.

\section{IDENTIFYING AS-MOBILISING BACTERIA VIA CORRELATION ANALYSIS OF IN SITU GEOCHEMICAL PROFILES \& HIGH-THROUGHPUT MICROBIAL COMMUNITY SEQUENCING}

Recent improvements in DNA sequencing and analysis, alongside the availability of carefully extracted and stored field samples, has made it possible to explore the in situ microbial ecology of sediments with high groundwater arsenic concentrations.

With colleagues in Barnard College and Columbia University (New York, USA) and the University of Dhaka (Bangladesh) we recently used a comprehensive suite of state-of-the art molecular techniques to better constrain the relationship between indigenous microbial communities and the iron and arsenic mineral phases present in sediments at two well-characterized arsenic-impacted aquifers in Bangladesh (Gnanaprakasam et al., 2017). First, we examined the hydrogeologies of the sediments and water samples from two contrasting sites (sites $\mathrm{F}$ and B), followed by analyses of the composition of bacterial communities (and key functional genes that could impact the As speciation) using next generation sequencing. We then explored correlations between the microbial community compositions and the data obtained from the hydrogeological analyses of the sediment cores and relevant water samples. At both sites, arsenate $[\mathrm{As}(\mathrm{V})]$ was the major species of As present in sediments at depths with low aqueous As concentrations, while most sediment As was arsenite [As(III)] at depths with elevated aqueous As concentrations. This was consistent with a role for the microbial As $(\mathrm{V})$ reduction in mobilizing arsenic. 16S rRNA gene analysis indicated that the arsenic-rich sediments were colonized by diverse bacterial communities implicated in both dissimilatory Fe(III) and $\mathrm{As}(\mathrm{V})$ reduction, while detailed correlation analyses suggested the involvement of phylogenetic groups not normally associated with As mobilization. Again, Geobacter species known to reduce both $\mathrm{Fe}(\mathrm{III})$ and $\mathrm{As}(\mathrm{V})$ and implicated in arsenic mobilization in previous studies were detected throughout and could play a critical role in arsenic release. In addition, Spearman rank correlations identified new phylogenetic groups that could be linked directly or indirectly with $\mathrm{As}(\mathrm{V})$ reduction and mobilization, and identification of their potential role in such processes warrants further investigation. However, given the complex microbial communities identified and the relatively low abundance of known metal-reducing bacteria, the organisms causing these problems are likely to constitute a relatively minor component of the microbial communities. The mobilization of arsenic in carbon-stimulated microcosms and pure culture lab experiments described previously are typically rapid (on the order of weeks). It is likely that under in situ conditions, these processes take longer to deliver the arsenic into the aqueous phase, consistent with higher arsenic waters that are several decades old. This would also be consistent with lower loadings of bioavailable organic material expected at depth and the relatively low abundance of metal-reducing bacteria in the microbial communities detected. The precise nature of the organic matter fueling metal reduction at depth clearly requires further investigation, as does the role of other potential electron donors, such as ammonium and methane, in such processes. This is a focus of our current work, alongside detailed metagenomic investigations of the microbial communities present in high arsenic aquifers in Cambodia, Bangladesh and Vietnam. These studies are already yielding molecular clues that we hope will lead to a better understanding of the microbial process that lead to arsenic mobilization in aquifers, and perhaps more importantly, competing microbial processes that may mitigate As contamination.

\section{ACKNOWLEDGEMENTS}

Funding from the Royal Society, Natural Environment Research Council (grant NE/P01304X/1) and NIEHS Superfund Research Program (grant P42 ES010349) are gratefully acknowledged.

\section{REFERENCES}

Akai, J., Lzumi, K., Fukuhara, H., Masuda, H., Nakano, S., Yoshimura, T., Ohfuji, H., Anawar, H.M. \& Akai, K. 2004. Mineralogical and geomicrobiological investigations on groundwater arsenic enrichment in Bangladesh. Appl. Geochem. 19(2):215-230.

Gnanaprakasam, E.T., Lloyd, J.R., Boothman, C., Ahmed, K. M., Choudhury, I., Bostick, B.C., Geen A.V. \& Mailloux B.J. 2017. Microbial community structure and arsenic biogeochemistry in two arsenic-impacted aquifers in Bangladesh. Mbio 8: e01326-17.

Islam, L.N., Nabi, A.M., Rahman, M.M., Khan, M.A. \& Kazi, A.I. 2004. Association of clinical complications with nutritional status and the prevalence of Leukopenia among arsenic patients in Bangladesh. Int. J. Environ. Res. Public. Health. 1(2): 74-82.

Rowland, H., Pederick, R., Polya, D.A., Pancost, R.D., van Dongen, B.E., Gault, A.G., Vaughan, D.J., Bryant, C., Anderson, B. \& Lloyd, J.R., 2007. The control of organic matter on microbially mediated iron reduction and arsenic release in shallow alluvial aquifers, Cambodia. Geobiol. DOI: $10.1111 /$ j.1472-4669.2007.00136.x. 